\title{
The Influence of Feed Intake and Conditioned Reflex on Exocrine Pancreatic Function in Broiler Chicks
}

\author{
Vladimir G. Vertiprakhov, Ivan A. Egorov \\ All-Russian Research and Technological Poultry Institute, Sergiev Posad, Russia \\ Email: Vertiprakhov63@mail.ru
}

How to cite this paper: Vertiprakhov, V.G. and Egorov, I.A. (2016) The Influence of Feed Intake and Conditioned Reflex on Exocrine Pancreatic Function in Broiler Chicks. Open Journal of Animal Sciences, 6 , 298-303.

http://dx.doi.org/10.4236/ojas.2016.64034

Received: July 5, 2016

Accepted: October 22, 2016

Published: October 25, 2016

Copyright $\odot 2016$ by authors and Scientific Research Publishing Inc. This work is licensed under the Creative Commons Attribution International License (CC BY 4.0).

http://creativecommons.org/licenses/by/4.0/

\section{(c) (i) Open Access}

\begin{abstract}
The data of an experimental study of the influence of feeding and the conditional stimulus on digestive function in birds is presented. It is stated that feed consumption is a powerful stimulator of pancreatic secretion in broiler chicks. The secretory response of the pancreas was the highest in the morning when secretion of pancreatic juice was 1.8 times higher, amylase activity 3.2 times, proteases activity 3.3 times, lipase activity 2.1 times higher than before feeding (basal levels). The regulation of pancreatic activity is known to be complex-reflex with conditioned-reflex component being very important since it provides $25 \%$ higher juice secretion and $42 \%-74 \%$ higher enzyme secretion compared to the basal levels during few minutes after the conditional signal.
\end{abstract}

\section{Keywords}

Pancreatic Juice, Pancreatic Enzymes, Broiler Chicks, Conditioned Reflex, Feeding

\section{Introduction}

Nutrition is the main factor affecting both qualitative and quantitative aspects of avian metabolism. The genetic potential of modern highly productive crosses of poultry can be embodied only if poultry is provided with quality feeds balanced in nutritional value, contents of vitamins and trace elements [1]. The efficiency of feeds, however, will depend on the efficiencies of digestion and absorption of nutrients, hence the studies on the digestive physiology in poultry are crucial for commercial poultry production.

Presently it is well known that avian digestion differs from mammalian in certain morpho-physiological peculiarities [2] [3] [4]. Though there is a lot of evidence on the 
influence of different feed additives and diets with different structures on the growth and nutritive balance in broiler chicks, the matters of the digestion itself are still not elucidated enough. The studies on the digestion in broilers are particularly vital in view of the continuous perfection of broiler crosses towards the improvement of growth rate and feed conversion. The aim of the study presented was to investigate the influence of feed intake and conditioned reflex on the exocrine pancreatic function in broiler chicks.

\section{Materials and Methods}

The study was conducted on 8 broiler chicks with pancreatic duct operationally transplanted at 1 month of age into an isolated section of the intestine to obtain the secrete of pancreatic juice [5]. This approach allows the collection of pancreatic juice during a trial while during the remaining time the juice can be redirected into the intestine via external anastomosis. The daily dynamics of the exocrine pancreatic function in broilers was studied in a series of trials ( $12 \mathrm{hrs}$ each with the interval of $30 \mathrm{~min}$ ). The trials were conducted at daytime under standard conditions of feeding: feed and water were given at 9 am, 1 and $5 \mathrm{pm}$, feed receipt being conformed to the Institute's recommendations [1]. The studies on the conditioned reflex were performed during $3 \mathrm{hrs;}$ collections of pancreatic juice for determination of enzymatic activities were performed with the interval of $30 \mathrm{~min}$. The natural conditional stimulus (sounds uttered by broilers at the beginning of feed distribution, or "feeding sound") was used as a conditional signal. This conditional signal was rendered during $5 \mathrm{~min}$. and subsequently supported by unconditioned reflex, delivery of feed (30 g per bird). The conditioned reflex was formed during 5 days; on day 6 the conditional stimulus was applied without delivery of feed to evaluate the contribution of conditioned reflex.

Activity of amylase was measured by Smith-Roy method modified by Ugolev [6]; proteases by casein degradation with colorimetric control [7]; lipase by hydrolysis of sunflower oil [8]. The statistical analysis of the data obtained was performed using standard Student's t-test.

The birds were kept and cared in accordance with principles of the humane treatment of animals (Federal draft law "On the responsible treatment of animals", No. 458458-5, July 1, 2010, Russian Federation).

\section{Results and Discussion}

The results of our trials show that pancreatic juice in broilers is secreting continuously. However at daytime exocrine pancreatic function undergoes some changes related primarily with feeding (Figure 1 \& Figure 2).

During the first hour after the morning meal at 9 am the secretion of pancreatic juice increased from $0.9 \pm 0.06$ to $1.6 \pm 0.07 \mathrm{ml}$ (or by 1.8 times) with the subsequent plateau at the same level during the following 3 hours until the next meal at $1 \mathrm{pm}$. Midday meal increased the secretion of pancreatic juice from $1.5 \pm 0.09$ to $1.7 \pm 0.08 \mathrm{ml}$ or by $13.3 \%$ ( $\mathrm{p}<0.05$ ). The latter level of secretion remains constant during the following 3 hours with the subsequent decrease to $1.4 \pm 0.07 \mathrm{ml}$ and increase after evening meal at $5 \mathrm{pm}$ 


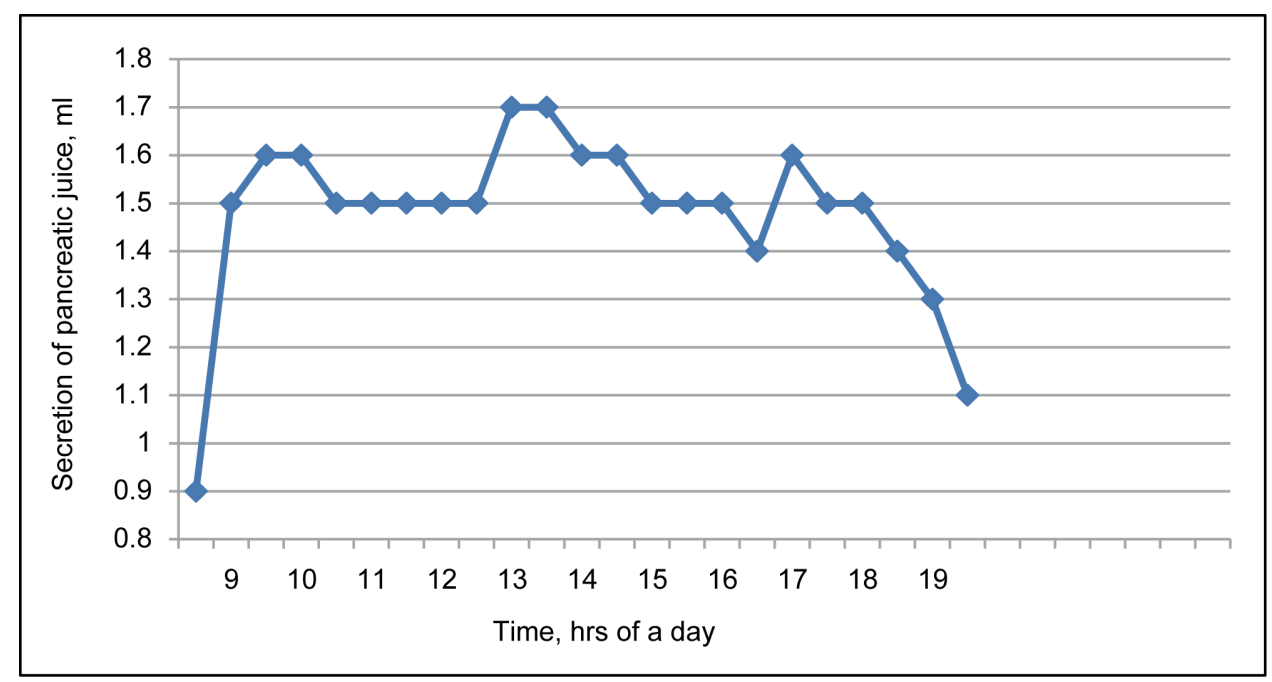

Figure 1. The dynamics of secretion of pancreatic juice in broilers.

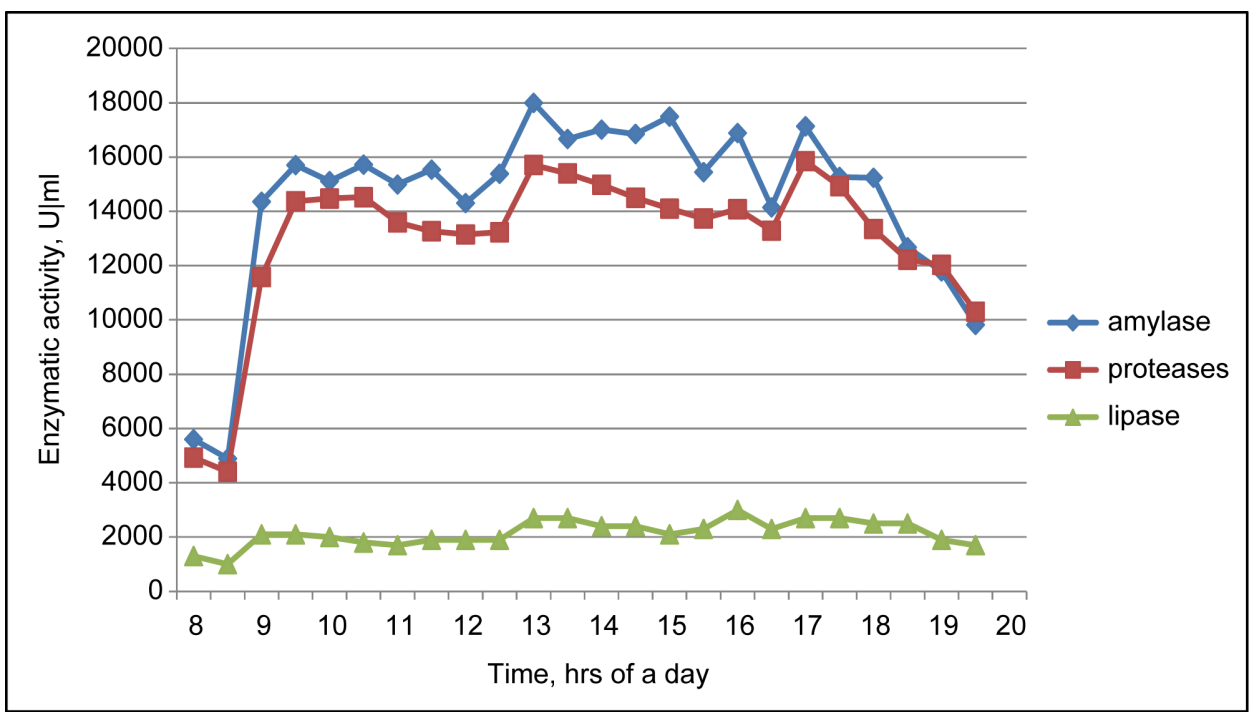

Figure 2. The daytime dynamics of enzymatic activities in pancreatic juice of broilers (figures for proteases are $\times 10$, for lipase $\times 100)$.

to $1.6 \pm 0.06 \mathrm{ml}(\mathrm{p}<0.05)$. After that the secretion decreases again and reaches $1.1 \pm$ $0.07 \mathrm{ml}$ in 2.5 hours after the evening meal.

The pattern of daytime dynamics of enzymatic activities also featured increases related to the meals. The highest activity peaks were found at $1 \mathrm{hr}$ after the morning meal: proteases from $441 \pm 43.9$ to $1437 \pm 86.2 \mathrm{mg} / \mathrm{ml} / \mathrm{min}$ (or by 3.3 times); amylase from $4891 \pm 452.4$ to $15,703 \pm 977.9 \mathrm{mg} / \mathrm{ml} / \mathrm{min}$ (or by 3.2 times); lipase from $10 \pm 1.1$ to 21 $\pm 1.8 \mu \mathrm{M} / \mathrm{ml} / \mathrm{min}$ (or by 2.1 times). This high level of pancreatic secretion and enzymatic activities remains nearly constant during the subsequent $3 \mathrm{hrs}$ with the next increase related to the following meal. After the midday meal the secretion of juice and enzymes reaches maximum levels as early as in $30 \mathrm{~min}$ after the meal. The secretory pancreatic response to the midday meal after relatively high pre-meal levels is substan- 
tially lower compared to the response to the morning meal after the preceding night of starvation: secretion of pancreatic juice is found to increase by $13 \%$, amylase activity by $17 \%$, proteases by $19 \%$, lipase by $42 \%$ compared to the pre-meal levels.

The increase in pancreatic secretory activity after the midday meal is lesser than that after the morning meal though maximal levels of activities found after the midday meal are higher than those after the morning meal: juice secretion by $6 \%$, amylase activity by $15 \%$, proteases by $9 \%$, lipase by $30 \%$ compared to the maximal levels found after the morning meal. Then these activities decrease and in $3 \mathrm{hrs}$ after the midday meal reach pre-meal levels.

Evening meal at $5 \mathrm{pm}$ also increases the secretion of pancreatic juice from $1.4 \pm 0.07$ $\mathrm{ml}$ to $1.6 \pm 0.06 \mathrm{ml}$ (by 14.3\%) with return to the pre-meal level in $2 \mathrm{hrs}$ post-meal. In the first $30 \mathrm{~min}$ after this meal activity of amylase increases from 14,146 \pm 711.2 to $17,133 \pm 614.6 \mathrm{mg} / \mathrm{ml} / \mathrm{min}$ (by $21.1 \%$ ), proteases from $1329 \pm 68.0$ to $1585 \pm 94.2$ $\mathrm{mg} / \mathrm{ml} / \mathrm{min}$ (by $19.3 \%$ ), lipase from $23 \pm 1.8$ to $27 \pm 1.8 \mu \mathrm{M} / \mathrm{ml} / \mathrm{min}(17.4 \%)$. The increase of enzymatic activities after the evening meal is therefore similar to the increase after the midday meal; however, these increased activities decrease and reach basal pre-meal levels much faster than after the midday meal.

The most substantial response of the pancreas to feed intake was therefore found in the morning when enzymatic activities were increasing by 2.1 - 3.3 times. The activities of pancreatic enzymes remained quite high during the entire daytime period (with slight variations) with the subsequent substantial decrease to the basal starvation levels after $7 \mathrm{pm}$.

The regulation of pancreatic secretory activity includes complex-reflex phase starting immediately after a meal; this phase could be divided into unconditional-reflex and conditional-reflex responses. Unconditioned reflexes are genetically established while conditioned ones are forming during the ontogenesis. The results of our experiment showed that rendering of "feeding sound" signal at day 6 (after 5 days of preliminary forming of the reflex) the secretion of pancreatic juice tended to increase from $1.2 \pm$ $0.19 \mathrm{ml}$ to $1.5 \pm 0.18 \mathrm{ml}$ (by $25 \%$ ) in 6 broilers out of 8 during 30 min after the signal with the subsequent decrease to the level of $1.2 \pm 0.24 \mathrm{ml}$ lasting for the next $2 \mathrm{hrs}$ until the end of the trial (Table 1).

Enzymatic activities also tended to increase after the "feeding sound" signal especially in the first juice sample obtained after the signal. Activity of amylase in this sample increased by $74.0 \%$ with the subsequent decrease back to the initial level. Activity of proteases after the sound stimulus increased by $42.2 \%$, lipase by $55.0 \%$ compared to the initial levels (prior to the stimulus); then the activities decreased to the levels similar to the basal ones.

Natural stimuli can therefore develop persistent conditioned reflexes in broilers older than 1 month of age. Exocrine pancreatic function significantly increased in the first 30 min after the sound stimulus. The effect of conditioned stimulus merely ("feeding sound" non-strengthened by the unconditioned stimulus, i.e. feeding itself) on the pancreatic activity was half lesser than the effect of unconditioned stimulus (feeding 
Table 1. The influence of conditional stimulus ("feeding sound") on exocrine pancreatic function in broiler chicks.

\begin{tabular}{ccccc}
\hline \multirow{2}{*}{$\begin{array}{c}\text { Periods of juice } \\
\text { collection } \\
(\text { hrs.min am })\end{array}$} & $\begin{array}{c}\text { Secretion of } \\
\text { pancreatic } \\
\text { juice, } \mathrm{ml}\end{array}$ & $\begin{array}{c}\text { Amylase, } \\
\mathrm{mg} / \mathrm{ml} / \mathrm{min}\end{array}$ & $\begin{array}{c}\text { Proteases, } \\
\mathrm{mg} / \mathrm{ml} / \mathrm{min}\end{array}$ & $\begin{array}{c}\text { Lipase, } \\
\mu \mathrm{M} / \mathrm{ml} / \mathrm{min}\end{array}$ \\
\cline { 3 - 5 } $8.30-9.00$ & $1.2 \pm 0.19$ & $4508 \pm 1272.8$ & $386 \pm 72.1$ & $6.0 \pm 1.53$ \\
9.00 (signal) -9.30 & $1.5 \pm 0.18$ & $7843 \pm 1754.7^{*}$ & $549 \pm 75.1^{*}$ & $9.3 \pm 1.26^{*}$ \\
$9.30-10.00$ & $1.2 \pm 0.24$ & $4496 \pm 1994.4$ & $349 \pm 49.7$ & $6.4 \pm 1.54$ \\
$10.00-10.30$ & $1.3 \pm 0.29$ & $5082 \pm 1520.1$ & $419 \pm 57.5$ & $10.3 \pm 2.80$ \\
$10.30-11.00$ & $0.9 \pm 0.19$ & $3024 \pm 993.0$ & $432 \pm 142.2$ & $6.3 \pm 1.26$ \\
$11.00-11.30$ & $1.2 \pm 0.17$ & $4252 \pm 1234.7$ & $413 \pm 60.7$ & $6.7 \pm 1.54$ \\
\hline
\end{tabular}

${ }^{*}$ Difference with other figures in a column is significant, $\mathrm{p}<0.05$.

without sound stimulus). Another difference between these effects is that the effect of conditioned stimulus will last for $30 \mathrm{~min}$ after the stimulation and then drop down while the effect of unconditioned stimulus (feeding) is expressed more markedly and will last for $60-120 \mathrm{~min}$. A regularity in enzyme secretion between individuals was also found: the higher were the basal levels of secretion (after starving at night) the lower will be the increases post-meal, and vice versa. This regularity could be conditioned by functional type of higher nervous system in chicken and/or individual level of functional activity of the pancreas.

Our data are consistent with the earlier data by Batoev [4] who studied daily dynamics of exocrine pancreatic function in laying hens, ducks, and geese. The secretion of pancreatic juice in broiler chicks was however found to be much higher compared to laying hens, by $3.4 \mathrm{ml} /$ day of juice per $1 \mathrm{~kg}$ of live bodyweight (31.4 vs. $28.0 \mathrm{ml} /$ day, respectively). Activity of proteases in pancreatic juice in broilers was $1059 \pm 87.5$ $\mathrm{mg} / \mathrm{ml} / \mathrm{min}$, substantially higher compared to laying hens (532 \pm 26$)$, ducks (622 \pm 63 ), and geese $(250 \pm 25)$. This author also showed that regulation of exocrine pancreatic function is not related to the unconditioned reflexes solely but also involves a conditioned-reflex mechanism.

\section{Conclusion}

Feed intake is a powerful stimulus affecting pancreatic secretion in broiler chicks. The most substantial response to this stimulus was found in the morning after the first feeding after the starvation at night: secretion of pancreatic juice increased by 1.8 times, amylase activity by 3.2 times, proteases by 3.3 times, and lipase by 2.1 times. The regulation of pancreatic function is complex-reflex with considerable participation of conditioned component: the application of conditioned stimulus only increased the secretion of pancreatic juice by $25 \%$ and enzymatic activities in it by $42 \%-74 \%$ compared to the basal levels. This effect should be necessarily taken into account in practical nutrition of poultry. 


\section{Acknowledgements}

This research and the publication were financed by Russian Science Foundation, grant No 16-16-04089.

\section{References}

[1] Fisinin, V.I., Egorov, I.A., Lenkova, T.N., Okolelova, T.M., Ignatova, G.V., et al. (2014) A Guidebook on the Optimization of Diets for Poultry. All-Russian Research and Technological Poultry Institute, Sergiev Posad. (In Russian)

[2] Georgievsky, V.I. (1978) Digestion in Birds. In: Georgievsky, V.I., Ed., Physiology of Productive Animals, Nauka, Leningrad, 80-130. (In Russian)

[3] Berdnikov, P.P. (1990) The Secretory Function of Digestive Glands and Availability of Nutrients from the Diets in Ducks. PhD Thesis, State Agricultural Academy, Moscow. (In Russian)

[4] Batoev, Ts.Zh. (2001) The Digestive Physiology of Birds. Buryat State University Publ., Ulan-Ude. (In Russian)

[5] Batoev, Ts.Zh. and Batoeva, S.Ts. (1970) The Method of Fistulation of Birds for Investigations on Pancreatic Function and Bile Secretion. Physiological Journal of USSR, 56, $1867-$ 1868. (In Russian)

[6] Merina-Gluzkina, V.M. (1965) The Comparative Evaluation of Saccharizing vs. Dextrinizing Methods of Determination of Amylase Activity in Intact Humans and Patients with Acute Pancreatitis. Laboratornoye Delo, No. 3, 143. (In Russian)

[7] Batoev, Ts.Zh. (1971) Photometric Analysis of Proteolytic Enzymatic Activities in Pancreas and Its Juice Using the Decrease in Casein Concentration as a Criterion. The Proceedings of Buryat Agricultural Institute, No. 25, 122-126. (In Russian)

[8] Batoev, Ts.Zh. and Tsybekmitova, G.Ts. (1985) The Determination of Lipase Activity in Pancreatic Juice Using the Reaction of Hydrolysis of Sunflower Oil. In: Berdnikov, P.P., Ed., Diseases of Agric, Animals in Transbaikalia and Far East and Methods of Treatment, Blagoveshchensk Agricultural Institute, Blagoveshchensk, 70-73. (In Russian)

Submit or recommend next manuscript to SCIRP and we will provide best service for you:

Accepting pre-submission inquiries through Email, Facebook, LinkedIn, Twitter, etc.

A wide selection of journals (inclusive of 9 subjects, more than 200 journals)

Providing 24-hour high-quality service

User-friendly online submission system

Fair and swift peer-review system

Efficient typesetting and proofreading procedure

Display of the result of downloads and visits, as well as the number of cited articles

Maximum dissemination of your research work

Submit your manuscript at: http://papersubmission.scirp.org/

Or contact ojas@scirp.org 